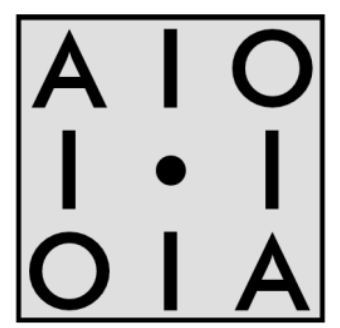

Attic Inscriptions Online

\title{
The Inscribed Version of the Decree Honouring Lykourgos of Boutadai (IG II 457 and 3207)
}

\author{
S. D. Lambert
}

AIO Papers no. 6

14 February 2015

Links added: May 2016 


\author{
AlO Papers \\ Published by Attic Inscriptions Online, 97 Elm Road, Evesham, \\ Worcestershire, WR11 3DR, United Kingdom. \\ Editor: Dr. S. D. Lambert \\ AIO Advisory Board: Professor P. J. Rhodes (Durham) \\ Professor J. Blok (Utrecht) \\ Dr. A. P. Matthaiou (Athens) \\ Mr. S. G. Byrne (Melbourne) \\ Dr. P. Liddel (Manchester) \\ (C) Attic Inscriptions Online 2015
}

All rights reserved. No part of this publication may be reproduced, stored in a retrieval system, or transmitted, in any form or by any means, without the prior permission in writing of Attic Inscriptions Online, or as expressly permitted by law, or under terms agreed with the appropriate reprographic rights organisation. Enquiries concerning reproduction should be sent to Dr. S. D. Lambert at the above address or via the contact given at www.atticinscriptions.com. 


\title{
THE INSCRIBED VERSION OF THE DECREE HONOURING LYKOURGOS OF BOUTADAI (IG II 457 AND 3207) ${ }^{1}$
}

\author{
S. D. Lambert
}

\section{The Association of $\underline{I G ~} \|^{2} 457$ and $\underline{I G ~} \|^{2} 3207$}

The two non-joining fragments of $I G \|^{2} 457$ (EM 7249) preserve sections of the upper part of the inscribed version of the decree honouring posthumously the orator Lykourgos of Boutadai, proposed by Stratokles of Diomeia in 307/6 BC. A complete version of the same decree, deriving from the application of Lykourgos' eldest son, Lykophron, for dining rights (sitesis) in the city hall (prytaneion) under the terms of the decree, and perhaps ultimately from the papyrus version of the decree in the city archive in the Metroon, is preserved in an Appendix to the Life of Lykourgos attributed to Plutarch ([Plut.] Lives of the Ten Orators 851e-852).

IG $\|^{2} 3207$ (EM 10679) preserves the lower portion of a stele inscribed with crowns in three columns. Within each crown the awarding body is given, followed by the name of the proposer. Of the first column of crowns nothing substantive is legible beyond the demotic of the proposer of crown 1, who was from Myrrhinous. The second and third columns record the following decrees:

$\begin{array}{ll}\text { col. } 2 & \text { col. } 3 \\ \text { crown } 5 & \begin{array}{l}\text { crown } 9 \\ \text { The Council. }\end{array} \\ \text { Themeas of Sphettos } & \text { Theomenes of Oe } \\ \text { proposed. } & \text { proposed. } \\ \text { crown } 6 & \text { crown } 10 \\ \text { The Council. } & \text { The People. } \\ \text { Diophanes of Kephisia } & \text { Theomenes of Oe } \\ \text { proposed. } & \text { proposed. }\end{array}$

\footnotetext{
${ }^{1}$ I am grateful to Athanasios Themos for permission to examine the stones in the Epigraphical Museum in December, 2014, to him, Eleni Zavvou and Stergios Tzanekas for discussion of the association of $\underline{457}$ and $\underline{3207}$; to Angelos P. Matthaiou for joining in the examination, for his wise observations and for comments on a draft of this paper; to Adele Scafuro for an account of her own consultations about this inscription earlier in 2014, for reading a draft of this paper and showing me a draft of a paper of her own which will discuss the commemoration of decrees on $I G \|^{2} 3207$ in the context of comparable monuments. I acknowledge with thanks a contribution of Utrecht University towards the cost of my visit to Athens and thank Josine Blok and P. J. Rhodes for reading a draft. This paper should be read in conjunction with the translation on AIO of $I G\|\|^{2} 457+3207$ and the accompanying notes, which have been revised to coincide with its issue. IALD = Inscribed Athenian Laws and Decrees, 352/1-322/1 BC. Epigraphical Essays (2012). Polis and Theatre = "Polis and Theatre in Lykourgan Athens. The Honorific Decrees", in A. P. Matthaiou and I. Polinskaya eds., Mikros Hieromnemon. Meletes eis mnemen Michael H. Jameson (2008), 53-85. IG $\|^{2}$ references for inscriptions in $I G \|^{3}$ can be traced via the main AIO site.
} 
crown 7

The Council.

Ktesikles

of Bate proposed.

crown 8

The tribesmen.

Telemachos

of Acharnai proposed. crown 11

The People

in Samos. Epiktetos

of Epikephisia proposed.

\section{crown 12}

The People in Lemnos. Timodemos of Acharnai proposed.

This stele commemorated, in brief, multiple awards of crowns to someone who was, it seems, quite prominent. Crown 11 must have been awarded in the period of the Athenian cleruchy on Samos (i.e. before 322/1). In 1911 the great Austrian epigraphist, Adolf Wilhelm, suggested that the honorand was Lykourgos of Boutadai, whose career peaked $336-325,{ }^{2}$ and that 3207 might be from the same stele as $\underline{457} .{ }^{3}$ In 1925 he justified that opinion more fully. ${ }^{4}$

We may eagerly anticipate Graham Oliver's fresh edition of this inscription for $I G \|^{3}$, which will offer a fully considered revision of the text. My more limited purpose here is to report the results of a brief examination of the stones in December 2014, directed at reviewing whether $\underline{3207}$ belongs to the same stele as $\underline{457}$, and to make a few remarks about the decrees commemorated on 3207.

As Wilhelm noted, the rather abraded script on 3207 , though it makes a somewhat more careless impression, is similar in style to that on the well preserved $457 \mathrm{fr}$. b. Assuming the stones thickened and widened towards the bottom, the fragments display compatible thickness (as recorded by Wilhelm: $\underline{457} a, 0.115 ; \underline{457} \mathrm{~b}$, $0.12 ; \underline{3207}, 0.135$ ) and width (as calculated by Wilhelm: $457 \mathrm{~b}, 0.45 ; \underline{3207}$, over 0.48 ), and the marble is also of the same type (white, "Pentelic"). Angelos Matthaiou and I concur with Wilhelm that $\underline{3207}$ is compatible with $\underline{457}$ in these respects and that the stones may belong to the same inscription. In our opinion, however, this is not a necessary inference. ${ }^{5}$ The fragments of 457 have a rough-picked back. The back of 3207 , on the other hand, is different. At some point it acquired a highly smoothed finish. Later, apparently as part of a secondary use which created a socket in the back, behind the left edge of the front surface, roughly half way down, numerous cuts have been made in the reverse face of the stele to roughen the surface. These cuts extend about half way across the back of the stele from the edge with the socket. If the smooth back of $\underline{3207}$ is original (which is unclear), the stone does not belong to the

\footnotetext{
2 The dating of the decrees to about this time is confirmed by the prosopography of the proposers (see further below). Moreover, Lykourgos's tribe (Oineis) corresponds with the tribe which awarded crown 8 (Oineis, implied by the demotic of the proposer, Telemachos of Acharnai).

${ }^{3}$ Zeitschrift für die österreichischen Gymnasien 1911, 1030 (non vidi).

${ }^{4}$ Attische Urkunden III = Sitzungsberichte der Akademie der Wissenschaften in Wien 202 (1925), 3-6 = Akademieschriften zur griechischen Inschriftenkunde I (1974), 463-66.

${ }^{5}$ I am especially grateful to Mr Tzanekas of the Epigraphical Museum for discussing his reservations about whether $\underline{457}$ and $\underline{3207}$ belong to the same stele.
} 
same inscription as 457 . If it is not original, and an original rough-picked back has been smoothed in a secondary use, the full thickness of the bottom of the stele must originally have been rather greater than 0.135 , implying a very significant thickening of the stele towards the bottom. Moreover, there are extensive vertical fault-lines in $\underline{3207}$ which are not present in the fragments of 457 ; and Mr Tzanekas suggests that

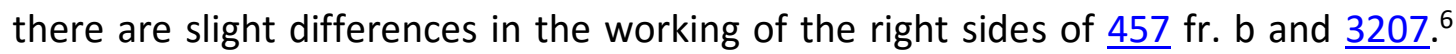
None of these points is decisive, but they do raise the possibility that $\underline{457}$ and $\underline{3207}$ belong to two separate, but associated, stelai. Such pairs of stelai are not unexampled. IG $\|^{3} 1,448$, for example, providing for a festival, and referring to the "stele about the Peace" (ten stelen tes peri tes eirenes), complements physically (script, thickness, same smoothly finished back) and in content the stele recording the Peace of Corinth, IG $\|^{3} 1,318$. Moreover, there is not always correspondence between the number of stelai provided for, or implicit, in the inscribing clause of a decree, and the number that were actually inscribed. IG $\|^{2} 140$, the law of Meid- amending the law of Chairemonides, and specified to be added to the stele recording that law, was actually erected on a separate stele. $I G \|^{3} 1,375$, the decree honouring Lapyris of Kleonai, specified for erection eis ten stelen for Echenbrotos of Kleonai $\left(=I G \|^{2} 63\right)$ was also inscribed on a separate stele.

The inscribed version of Stratokles' decree does not preserve the inscribing clause. The version in [Plut.], however, concludes as follows:

"and the secretary of the People shall set up for him (or about him, MSS of him), and there shall be valid, all the decrees on stone stelai and erect them on the acropolis near the dedications; and the treasurer of the People shall give for inscribing the stelai fifty drachmas from the People's fund for expenditure on decrees." 7

The decrees in question are the decree of Stratokles and the decrees inscribed in brief on 3207 . There is a clear implication that there are to be multiple stelai. This may not have been followed through; in the event only one stele may have been

\footnotetext{
${ }^{6}$ In Mr Tzanekas' opinion a tooth chisel has been used on $\underline{457} \mathrm{fr} \mathrm{b}$, and a tongue chisel on 3207.

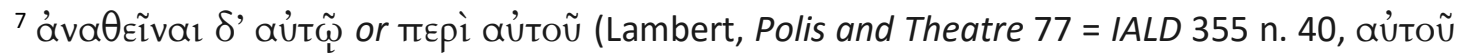

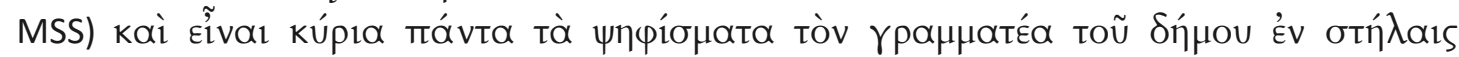

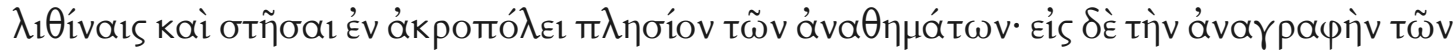

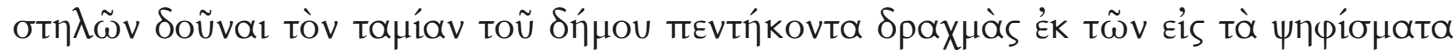

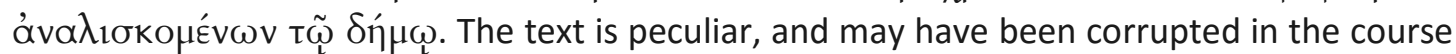
of transmission from the Athenian city archive to the medieval manuscripts of [Plut.], but the sense of the provision seems clear enough: all the decrees honouring Lykourgos are to be inscribed and erected on the acropolis "near the dedications". As noted IALD 355, n. 40, the language used here usually expresses the thought that decrees voted for or about someone should be valid ( $\underline{G \mid \|^{2} 275}, 5-7$, and other examples cited n. 40), not decrees proposed by them. That this is the correct interpretation is confirmed not only by $I G \|^{2} 3207$ but by the fact that the clause needs also to have covered the inscribing of Stratokles' own decree. Pace what I wrote there, laws and decrees might be referred to by the names of their proposers, as e.g. "the law of Chairemonides", IG II 140 , though use of a pronoun ("his decrees") in such a sense in this context seems to me difficult; and in the Lykourgan period note the characteristically both more correct and more collectivist formulation at $I G \|^{3} 1,327,25-26$, "the [decree] of the Council, which Agasi- proposed, and the one of the People which Hippochares proposed".
} 
erected, with Stratokles' decree at the top, and the other decrees honouring Lykourgos commemorated in abbreviated form in crowns inscribed underneath. 50 drachmas is possible provision for a single inscription at this period. ${ }^{8}$ On other occasions, however, 20 or $30 \mathrm{dr}$. is provided for a single stele and $50 \mathrm{dr}$. is accordingly also possible provision for two stelai. In 323/2 (as reinscribed in 318) $50 \mathrm{dr}$. was provided for two copies of the decree honouring Euphron of Sikyon. ${ }^{9}$ It is therefore also quite plausible that this inscribing provision was put into effect by erecting a pair of stelai, one carrying Stratokles' decree (ㄴ7) and one carrying the other decrees

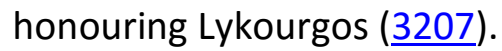

The stipulation that the stelai be set up on the acropolis "near the dedications" is remarkable on two counts. First, because it would seem that no copy of Stratokles' decree was to be erected alongside the bronze statue of Lykourgos in the Agora, provided for in the decree. ${ }^{10}$ Though we know of several earlier awards of statues to Athenians, ${ }^{11}$ this is the earliest extant inscribed decree making such an award. In the case of the early fourth-century statue for Konon, it seems that there was an inscribed decree, as Demosthenes 20.69 quotes "from the stele"; but it may not have been usual, or at least not invariable, practice to inscribe decrees awarding statues alongside the statue.

Second, specific locations on the acropolis were rarely named in inscribing clauses of decree stelai, ${ }^{12}$ and the stipulation, "near the dedications", is unique. It was

\footnotetext{
${ }^{8}$ W. T. Loomis, Wages, Welfare Costs and Inflation in Classical Athens (1998), 143-44, no. 137, notes that $50 \mathrm{dr}$. was provided in this same year for inscribing the law on the repair of the long walls ( $\left.I G \|^{2} 463,33-34\right)$ and, no. 146, in ca. 307-302 $50 \mathrm{dr}$. for a citizenship decree $\left(I G \|^{2}\right.$ 518 + Osborne, Naturalization D54, 5-9; also for the decree honouring ambassadors from Carthage, IG $\|^{2} 418$ = Loomis no. 127, work of Tracy's "Cutter of $I G \|^{2} 1262^{\prime}$, ca. 320-296, Athenian Democracy in Transition [1995], 138).

${ }^{9}$ IG $\|^{3} 1,378,31$. M. J. Osborne, ZPE 42 (1981), 173-74, noted the possibility that $50 \mathrm{dr}$. in Stratokles' decree was intended to cover two stelai in connection with his theory (since refuted, see SEG 49.107 and S. V. Tracy, Athens and Macedon [2003], 70-73) that IG $\|^{2} 513$ was a second copy of Stratokles' decree for Lykourgos.

${ }^{10}$ The statue was to be erected in the Agora except where the laws forbid (852e), probably a reference to the prohibition on erection next to the statues of Harmodios and Aristogeiton stipulated in our earliest surviving text of a decree awarding a statue, $I G \|^{2} 450$ of 314/3 for Asandros of Macedon, = Lambert, ABSA 95 (2000), 486-89 no. E1. According to [Plut.] 843c Lykourgos' statue was located in the Kerameikos. One wonders if this was deliberately in proximity to the public funerary monuments in the Kerameikos for Lykourgos' ancestors, Lykomedes and Lykourgos (852a) (on which see A. P. Matthaiou, Horos 5 [1987], 31-44, and most recently N. T. Arrington, Hesperia 79 (2010), 499-539 at 520). The statue was seen by Paus. 1.8.2 (mentioned after the statues of the eponymous heroes in the Agora, but not precisely located). A fragment of what is apparently its base, inscribed with Lykourgos's name, was discovered at the "Agora gate" (IG II 3776$)$. The statue is S20 in the catalogue of Athenian portrait statues compiled by G. J. Oliver, "Space and the Visualization of Power in the Greek Polis. The award of portrait statues in decrees from Athens", in P. Schultz and R. von den Hoff, Early Hellenistic Portraiture (2007), 181-204, at 185.

${ }^{11}$ Oliver, op. cit.

${ }^{12}$ On the rare occasions they are specified it is usually because specific factors in the decree drew the inscription to particular location on the acropolis, as e.g. the decree concerning objects in the chalkotheke, IG $\|^{2} 120$, to be set up "in front of the chalkotheke", see P. Liddel, ZPE 143 (2003), 79-93, at 81 with 86, table 2.
} 
normal in decree language to distinguish between a "stele" and a "dedication" (anathema), the former typically thinner and taller and bearing the text of a decree, the latter more squat and thick and carrying the object dedicated..$^{13}$ There is some conceptual overlap, however, and there are ambiguous cases and hybrids. ${ }^{14}$ This is one such hybrid, as not only are the stelai to be located "near the dedications" (rather than, it seems implied, with other decree stelai on the acropolis), the inscribing clause uses both the verb anatheinai, "set up", cognate with and normally used for dedications (anathemata), and stesai, "stand", normally used of stelai. To understand the background here we need to bear in mind that decrees honouring Athenians (never those honouring foreigners) with the more routine award of a crown were sometimes inscribed not on regular "stelai", but, from the 340s onwards, on dedications, usually, but not always, bases for statues. Where such dedications were provided for in the decree, however, though they might be funded by the city, they were not usually made by the city, but by the honorands. ${ }^{15}$ In this case the honorand is dead and not in a position to make a dedication; the responsibility is taken over by the city. Though the decrees for Lykourgos were to be inscribed on stelai, therefore, language and location assimilates them to dedications made by Athenian officials commemorating, and inscribed with, decrees awarding them crowns.

There is also, however, another possible factor in the background here, for the honorand had a special connection with the acropolis as member of the genos Eteoboutadai, which supplied the priests of Poseidon Erechtheus and the priestesses of Athena Polias. Broadly contemporary with this bronze statue (the precise timing can not be pinned down), there were wooden statues of Lykourgos and his sons in the Erechtheion, made by Timarchos and Kephisodotos, sons of Praxiteles, and Lykourgos' son Habron set up a tablet (pinax) there illustrating the succession of the priests of Poseidon Erechtheus ([Plut.] 843e-f). ${ }^{16}$ Perhaps the (or a) point of the inscribing clause of Stratokles' decree was to clarify that the inscription was not to be placed among the monuments of the Eteoboutadai, but in public space alongside the regular dedications.

\footnotetext{
${ }^{13}$ The distinction is observed, for example, in the five decrees inscribed on the dedication by the Council of 343/2, set up at the initiative of Phanodemos, $I G \|^{3} 1,306$, where the Council's decree honouring Phanodemos for his performance as councillor (decree 3 ), is both to be inscribed "on the dedication" (I. 8, i.e. the surviving monument), and also to go forward as a probouleuma to the Assembly, which, if passed by the Assembly, was to be inscribed on a stele on the acropolis (I. 15, no such monument survives).

${ }^{14}$ E.g. $I G \|^{3} 1,360$, a base in the form of a thick stele, referred to as a dedication in I. 1 , a stele in I. $54 ; 417$, a block from a dedication of uncertain physical type, apparently referred to as a stele in I. 24 (unless this decree was also inscribed separately on a stele, cf. previous note); $\underline{I G}$ $\underline{1 I^{2} 1156}$, same monument apparently referred to as a stele I. 35, a dedication II. 43-44, 49-51, 62-63.

${ }^{15}$ For a catalogue and discussion of decrees honouring Athenians of the period before 322/1, including physical format, see ZPE 150 (2004), 85-120, and 154 (2005), 125-29 = IALD 1-55. Examples of dedications at public expense, but made by the honorands: $\underline{I G \|^{3} 1,311}, 6 ; \underline{355}$, 36-37; 369, 48; $\underline{416}, 36$.

${ }^{16}$ Monuments relating to the priestesses of Athena Polias, including the earlier fourth-century statue of the long-serving priestess, Lysimache, $I G \|^{2} 3453$, may also have been erected in Eteoboutad space. See now C. M. Keesling, Hesperia 81 (2012), 476-505.
} 
The findspot of 3207, on the acropolis, is compatible with the inscribing clause of Stratokles' decree. So are the findspots of the two fragments of $\underline{457}$, which can be assumed, as not uncommonly with fragments of inscriptions originally set up on the acropolis, to have wandered down from it, fr. a to the church of Panagia Pyrgiotissa, south of the Stoa of Attalos, fr. b to the theatre of Dionysos.

To summarise the key points: $\underline{I G \|^{2} 3207}$, inscribed with summaries of decrees honouring Lykourgos of Boutadai passed in his lifetime, either (a) belongs to the same stele as $\underline{I G ~} \|^{2} 457$, containing Stratokles' decree honouring him posthumously, or (b) to a separate stele associated with it. The stele or stelai give effect to the inscribing clause of Stratokles' decree, which provides for erection of decrees for Lykourgos (i.e. both Stratokles' decree and the decrees passed in his lifetime) on "stelai" on the acropolis near the dedications. The use of the plural, "stelai", is prima facie more consistent with (b), but does not rule out (a), given that it was not uncommon for numbers of stelai implied by inscribing clauses of decrees to differ from numbers of stelai actually erected. The unique stipulation "near the dedications" resonates with other decrees honouring Athenians, some of which, since the 340 s, had been inscribed on dedications rather than regular stelai, but may also signify that the decrees were to be erected in the area of the acropolis normally used for dedications rather than the area of the acropolis (the Erechtheion) in which monuments were located relating to Lykourgos' genos, the Eteoboutadai, which already included, or was shortly to include, a wooden statue of him.

\section{The decrees commemorated in $\underline{I G \|^{2} 3207}$}

The great political rivals of the post-Chaironeia period, Demades and Lykourgos, proposed, by a considerable margin, more extant inscribed laws and decrees than any other Athenian politician of the classical democracy; ${ }^{17}$ and on two or three occasions

${ }^{17}$ Demades proposed eight or nine extant self-standing decrees erected before 321/0: (1) IG $1 \|^{3} 1,321$, of $337 / 6 ;(2) * 322$, of $337 / 6$, honouring a courtier of Philip II; (3)* possibly 330 , of $335 / 4$; (4) 334 , of $334 / 3$; (5) 335 , of 334/3, honouring Amyntor son of Demetrios; (6) $\underline{346}$ decree 2, of 332/1, for a son of Aristeides; (7) 356 , of 329/8, for a man from Larisa; (8)* 358 , of 328/7?, for Eurylochos of Kydonia; (9)* 384 , of 322/1. Lykourgos proposed at least eight: (1) $I G \|^{3} 1,329$, of $336 / 5$ or $335 / 4$, honouring a son of Eupor-, probably a foreigner, and, since it is probouleumatic in formulation, implying that Lykourgos was on the Council this year; (2) 336 , of 334/3?, perhaps honouring the general Diotimos for his expedition against pirates; (3) 337 decree 2 , of $333 / 2$, granting the merchants of Kition the right to own a plot of land on which to build a temple of Aphrodite; (4) 345 , of 332/1, honouring a son of [Eud?] ]emos of Plataia; (5) 352, of 330/29, honouring Eudemos of Plataia for his contribution to the building of the Panathenaic stadium; (6)* 357 , of 328/7, content unknown; (7) 432 , of 337-325, honouring Sopatros of Akragas for his contribution to the Athenian grain supply (cf. $\underline{495}$, with IALD 402); (8) $\underline{445}$, of ca. 335, law(s) on sacred objects. Among possible cases note $\underline{470}$, mentioning the skene (of the theatre of Dionysos?), with E. Csapo and P. Wilson, "The Finance and Organisation of the Athenian Theatre in the Time of Eubulus and Lycurgus", in E. Csapo, H. Goette, J. R. Green and P. Wilson eds., Greek Theatre in the Fourth Century BC (2014), 41517. No other Athenian proposed more than 3 or 4 extant inscribed decrees before 321/0. 
extant decrees were proposed by both men at the same Assembly. ${ }^{18}$ Both these phenomena can plausibly be interpreted to an extent as a product of their rivalry, for at this period the practice begins of highlighting proposers' names on inscribed decrees via devices such as allocating the name a line to itself and leaving space before or after it; $;^{19}$ and successful proposing of decrees in the Assembly, prominently displayed on inscribed stelai, erected by the decision, and at the expense, of the Assembly, can increasingly be regarded as an intentional expression of political influence. Moreover, in a political culture driven by philotimia (a value more explicitly embraced in decrees since the $340 \mathrm{~s}^{20}$ ), this "decree-proposer rivalry" can be identified as a factor underlying the increase in the numbers of extant decrees in the years after $338 .^{21}$

The large majority of inscribed decrees at this period were honorific, and political rivalry was also apparent in the pursuit by politicians of honours for themselves, and in challenging proposals of honours for opponents, most famously in Aeschines' challenge to Ktesiphon's proposal to bestow a crown on Demosthenes, a challenge which came to court in 330, at the height of the "Lykourgan" era, and elicited from Demosthenes what was to become the most famous speech in Greek oratory, Demosthenes 18 On the Crown. At the key moment in the rivalry between Lykourgos and Demades it was Lykourgos who was cast in the role of Aeschines, vehemently opposing the proposal of Kephisodotos to award a bronze statue and sitesis to his rival. The occasion is not explicitly attested, but was probably in 335 following the latter's remarkable diplomatic coup in securing a favourable deal for Athens following Alexander's destruction of Thebes. ${ }^{22}$ Four fragments of Lykourgos' speech survive (Lykourgos F9 Conomis). In the first he undertook to demonstrate that

18 These are: at an Assembly in 334/3, IG $\|^{3} 1,334$ and $\underline{335}$ (Demades) and probably $\underline{336}$ (Lykourgos); at the special Assembly in the theatre following the City Dionysia in Elaphebolion 332/1, 345 (Lykourgos), $\underline{346}$ (Demades); at an Assembly in Gamelion 328/7, 357 (Lykourgos), 358 (Demades).

${ }^{19}$ See A. S. Henry, The Prescripts of Athenian Decrees [Mnemosyne Supplement 49] (1977), 6366. Those decrees marked ${ }^{*}$ in the lists in $\mathrm{n} .17$ display this feature, which was to become more marked in the years after 307/6 (S. V. Tracy, Hesperia 69 [2000], 227-33). Cf. Lambert, "Some Political Shifts in Lykourgan Athens", in V. Azoulay and P. Ismard eds., Clisthène et Lycurgue d'Athènes. Autour du politique dans la cité classique (Paris, 2011), 175-90, at 18485.

${ }^{20}$ On this see Lambert, "What was the point of honorific decrees in Lykourgan Athens", in Lambert ed., Sociable Man. Essays on Ancient Greek Social Behaviour in Honour of Nick Fisher (2011), 193-214.

${ }^{21}$ This can be illustrated by a simple statistic: 25 extant inscribed decrees with identifiable proposers are datable to the 16 years, 354/3-339/8; nearly twice as many, 48, to the 17 years, $338 / 7-322 / 1$. Another factor underlying this statistic is the increasingly deliberate use of the inscribed honorific decree as a political lever to manipulate the performance of officials and the behaviour of foreigners in relation e.g. to the grain supply and the theatrical life of the city. Cf. Lambert, in G. Reger et al. eds., Studies ... Stephen V. Tracy (2010), 153-60 =IALD 37786.

22 In the Harpalos affair of 324/3 Dinarchos 1 Against Demosthenes 101 was to criticise Demosthenes for having condoned erection of a bronze statue of Demades in the Agora and permitted Demades to share sitesis in the prytaneion with the descendants of Harmodios and Aristogeiton. Cf. P. Brun, L'orateur Démade (2000), 78-83. 
"the decree was illegal and that the man was not worthy of the grant", ${ }^{23}$ and in the second he compared the extravagant honours claimed for Demades' modest achievements unfavourably with the outstanding achievements of Pericles and the modest honours with which he had contented himself:

"Pericles, having captured Samos and Euboea and Aegina, and built the Propylaia and the Odeion and the Hekatompedon, and having brought 10,000 talents of silver up to the acropolis, was crowned with a foliage crown". ${ }^{24}$

What of Lykourgos' own honours? The award of a statue and sitesis in Stratokles' decree was doubtless seen by Stratokles and Lykourgos' sons as an opportunity posthumously to even up the score against Demades; and it is notable in this context that Lykourgos' actions are presented in the decree as explicitly in opposition to Alexander, in contrast, implicitly, to Demades, whose success had been based on a policy of constructive diplomacy with the Macedonians. It is also notable that the only extant inscribed decree honouring Lykourgos in his lifetime is $I G\|\|^{3} 1,355$, of 329/8, proposed by Demosthenes of Lamptrai. Characteristically given the fierce commitment to the collective over the individual apparent in Lykourgos' Against Leokrates, he is honoured there, with a gold crown and money for sacrifice and a dedication, not as an individual, but as member of the board responsible for the management of the first celebration of the new Great Amphiaraia festival. Strikingly, his name appears in the list (I. 23) immediately before that of Demades (I. 24); joint service on such a board did not, of course, exclude political rivalry, as Demosthenes (of Paiania) and Aeschines had demonstrated on the embassies to Philip II in 346. ${ }^{25}$

How do the decrees commemorated on $\underline{3207}$ fit into the picture? The requirement at the end of Stratokles' decree to inscribe the decrees honouring Lykourgos follows through the claim earlier in the decree, that "having been deemed to have administered all these things justly, he was crowned many times by the city". ${ }^{26}$ "All these things" refers to Lykourgos' financial responsibilities and achievements as

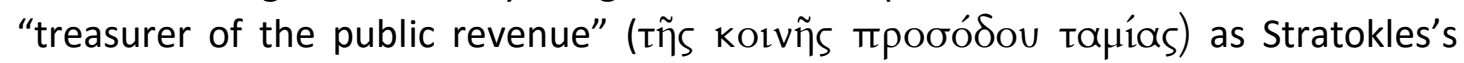
decree terms it, for three quadrennia. ${ }^{27}$ So, the implication seems to be that some or

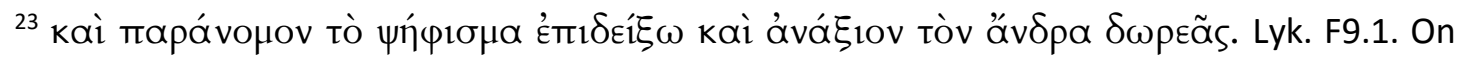
these and other fragments of Lykourgos see the helpful translation and notes of E. M. Harris in I. Worthington et al. transl., Dinarchus, Hyperides, and Lycurgus (2001), 204-18.

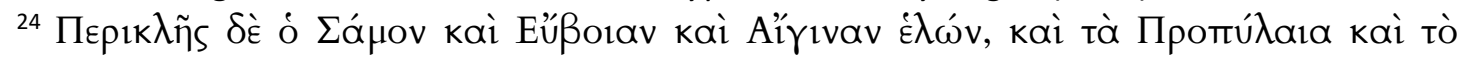

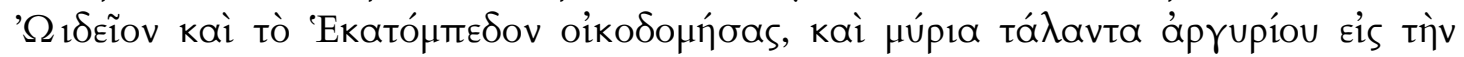

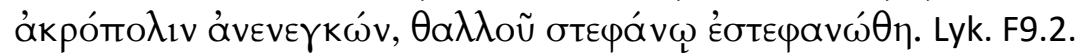

${ }^{25}$ Lykourgos and Demades also served together as hieropoioi on the Pythais of ca. 330-325, Syll. ${ }^{3} 296$ (a new edition of which will shortly be published in IG $\|^{3} 4$ fasc. 1 ), where again they are listed in consecutive lines ( 5 and 6$)$, perhaps because they were about the same age.

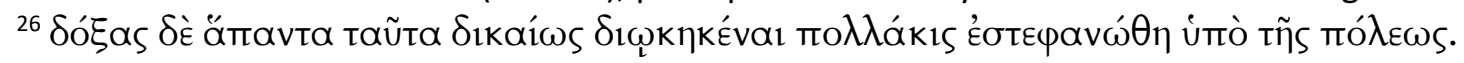
$852 \mathrm{~b}$.

${ }^{27}$ [Plut.] explains (841b-c) that Lykourgos held the office for the first quadrennium (probably $336 / 5-332 / 1$ ) in his own person, and subsequently, because tenure was prohibited for more

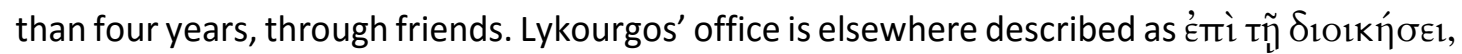
"in charge of the financial administration", most clearly at Hyp. F118, cf. D. Whitehead, Hypereides (2000), 448-50, but also implicitly e.g. in Lykourgos F5 and at $\underline{I G ~} \|^{3} 1,445,28$.
} 
all of the decrees commemorated on $\underline{3207}$ had recognised Lykourgos' tenure of this office. Awards of crowns to office-holders were subject to the satisfactory rendering of accounts (euthynai), and Lykourgos had not enjoyed an easy ride at the hands of his opponents. At some point he had to defend himself against Demades at a euthynai

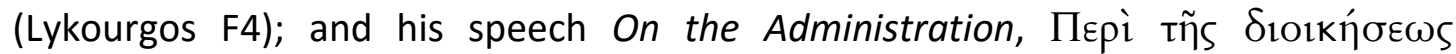
(Lykourgos F5) was also apparently delivered at a euthynai (cf. Dinarchos F4), perhaps after his first quadrennium in office. Most famously, on his deathbed Lykourgos had been carried into the Council-chamber and the Metroon to defend himself, "wishing

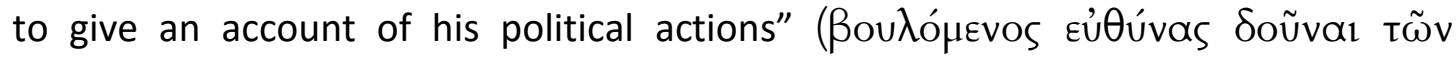

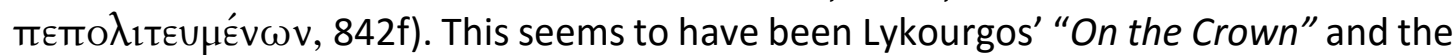
surviving fragments of his speech (Lykourgos F1) confirm that he ranged broadly across his career. ${ }^{28}$ The precise legal context is unclear; [Plut.] gives the impression that it was a euthynai, and it is usually thought to have been connected with Lykourgos' third quadrennium as "treasurer of the public revenue". If (what is not quite clear) the office was actually filled by one of his friends in his third term, it may have been formally a euthynai for the office-holder. According to [Plut.] 842f, he was vindicated on this occasion, and indeed on every other occasion according to Stratokles, ${ }^{29}$ but his opponent, Menesaichmos, pursued his sons after his death for non-payment of public debts owed by their father (842d-e), and they were saved by the intervention, among others, of Hypereides, and of Demosthenes from exile. ${ }^{30}$ Significantly, Lykourgos had clashed with Menesaichmos before; as we learn from his F14, he seems, characteristically, to have sought to condemn Menesaichmos at an eisangelia (the same heavy-handed process of "impeachment", intended for treasonable offences, that he had used against Leokrates) for sacrificing improperly on Delos.

Some of the crowns on 3207 , therefore, will have commemorated Lykourgos' tenure of financial office, and been awarded following or subject to successful completion of the euthynai to which these speeches relate. The number of crowns was at least 12, possibly more, even if Stratokles' decree was inscribed above the crowns; indeed, since $\underline{3207}$ can scarcely preserve as much as half the height of a stele, if the entire stele was occupied by crowns, the total number may have been up to 24 or more. In any case there are good grounds here for Stratokles' claim that he had been crowned "many times".

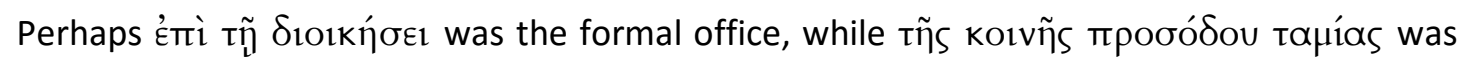
looser language comprehending the oversight Lykourgos exercised when his friends held office on his behalf. Cf. P. J. Rhodes, Chiron 37 (2007), 349-62.

${ }^{28}$ This speech presumably relates in some way to the account of his financial administration which he inscribed on a stele in front of the palaistra he had built ([Plut.] 843f). One may guess that this inscription and/or Lykourgos' speech on this occasion was a source for Stratokles' decree, whether directly or mediated via the biography of Lykourgos by his contemporary Philiskos (Olympiodoros, Comm. in Plat. Gorg. 515c, cf. M. Cuvigny [et G. Lachenaud], Plutarque. Oeuvres Morales XII 1, Traités 54-57 (Budé edition), $2^{\text {nd }}$ ed. Paris, 2003, 33). Philiskos was probably also a source for [Plut.] (who appears to have been a writer of the Augustan period, perhaps Caecilius of Cale-Acte, see Cuvigny, loc. cit.).

${ }^{29} 852$ d, cf. 842e.

${ }^{30}$ Hyp. F 118; Dem. Epist. 3; [Plut.] 842e. Cf. J. K. Davies, Athenian Propertied Families (1971), p. 351. 
Crowns 9 and 10, proposed by Theomenes of Oe in the Council and the Assembly respectively seem likely to belong to a single honorific process, culminating in a probouleumatic Assembly decree, originally proposed by Theomenes in the Council. Theomenes had been amphiktyon in accounts from Delos in 345/4 (ID 104$24,5)$, which is consistent with the possibility that the honours recognised Lykourgos' financial performance. One can only speculate that Theomenes might also have colluded with Lykourgos' prosecution of Menesaichmos on the matter of the Delian sacrifice.

The two cleruchic decrees, of Samos and Lemnos, are intriguing. Epiktetos of Epikephisia, proposer of 11 (Samos) is otherwise unknown; the proposer of 12 (Lemnos), was Timodemos of Acharnai, councillor in ca. 321 BC (Agora XV 54, 5) and apparently a descendant of the Timodemos of Acharnai whose victory in the pankration in the 480s was celebrated by Pindar, Nemean 2. Pindar's Timodemos was Salamis-bred, and might have been a member of the Athenian cleruchy on Salamis and/or of the genos Salaminioi, which probably implied landholding, but not necessarily residence, on the island. ${ }^{31}$ It is interesting indeed that the family seems also to have been a member of the Athenian community on another offshore possession, Lemnos; but there is scarcely a hint here of a connection with Lykourgos, unless it be a case of solidarity between old genos families, or unless these two cleruchic decrees were generated by appreciation for Lykourgos' measures against pirates. ${ }^{32}$

The proposer of the tribal decree commemorated by crown 8, Telemachos of Acharnai, is a name to conjure with. A well-known enough figure to be satirized by the comic poet Timokles for his busy politicking ("is the Acharnian Telemachos still making speeches?"33), and also, rather obscurely, for his consumption of beans - according to Athenaios he was always eating cooking pots of beans and celebrated the "Beanboiling" festival, Pyanopsia, as "festival of flatulence", 34 - he is indeed well-attested in the epigraphical record as proposer in the Assembly of three non-probouleumatic decrees: a very fragmentary decree of 339/8 for one Theophantos, IG $\|^{3} 1,315$; and two of the decrees (dating to between $330 / 29$ and $328 / 7$ ) honouring the grain trader, Herakleides of Salamis, that were inscribed under the terms of Demosthenes of Lamptrai's decree of 325/4 BC awarding Herakleides the proxeny $\left(I G \|^{3} 1,367\right)$. The first of the two (decree 1, II. 47-51) commissions the Council to come forward with a decree honouring Herakleides, and the second (decree 3, II. 29-46) builds in the Assembly on the resultant probouleuma, adding to the Council's proposed award of a crown, provision for an embassy to Dionysios, tyrant of Herakleia Pontica, seeking the return of Herakleides' sails, which had been confiscated there. ${ }^{35}$ Lykourgos had also

\footnotetext{
${ }^{31}$ See Lambert, ZPE 125 (1999), 118, cf. 128-30.

${ }^{32}$ See $I G \|^{3} 1,336$ with $\|^{2} 1623,276-85$ and [Plut.] 844a.

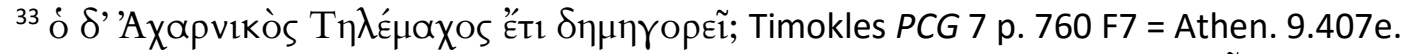

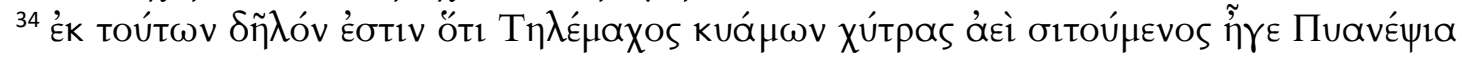

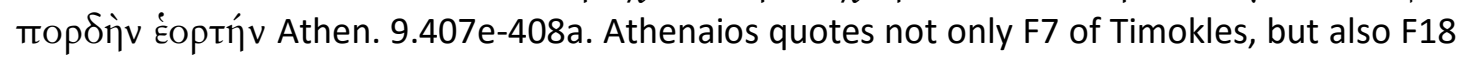
(407f) and F23 (407d-e). All three fragments connect Telemachos with pots of beans.

${ }^{35} \mathrm{It}$ is notable that the proposer of the probouleuma, Kephisodotos son of Euarchides of Acharnai, was from Telemachos' deme, pursuing his fellow demesman's proposal in a nice illustration of the way deme representation on the Council worked in practice. Telemachos of Acharnai was also a buyer of confiscated property sold by the poletai in Agora 19 P26, 496.
} 
participated in the policy of honouring grain traders to encourage them to supply Athens in the difficult years after Chaironeia, ${ }^{36}$ and one may perhaps detect here a common purpose with Telemachos. Demosthenes of Lamptrai may supply another point of connection, since, as we have seen, he was also the proposer of the decree honouring Lykourgos and other managers of the Great Amphiaraia in 329/8. It is possible that the Pyanopsia supplies another. Lykourgos had included a disquisition on this festival in his speech Against Menesaichmos (F14.2-3); and one wonders whether Telemachos' reputation in connection with bean-pots at this festival might have related to his appearance in the same case, or to proposals (satirized as flatulent?) made by him in the Assembly for reform or enhancement of the festival. Such proposals would not be unexpected in this period of intense preoccupation with the festival life of the city, including measures attested in the epigraphical record relating to the Panathenaia, Amphiaraia and Dipolieia. ${ }^{37}$

The decrees commemorated in the remaining three crowns, 5, 6 and 7, are of the Council only, so will have honoured Lykourgos for his conduct as councillor or in an office in which he was responsible to the Council. ${ }^{38}$ Ktesikles of Bate (crown 7) is otherwise unknown, though the demotic suggests a connection with Lykourgos' wife, Kallisto daughter of Habron of Bate, and/or with the branch of the Eteoboutadai which supplied the priestess of Athena Polias, which was based in that deme. ${ }^{39}$ Demeas of Sphettos (crown 5) is unknown, and Diophanes of Kephisia (crown 6) is known only as (or perhaps more likely as son of) the Diophanes son of Diophanes of Kephisia who was councillor in 367/6 (Agora XV 14.23). The relative obscurity of these three proposers of Council decrees is not very surprising. They may well have been more or less ordinary Athenians, taking the opportunity of their turn on the Council to associate themselves with a "big man." 40

For a man whose public persona radiated austere moral integrity, and who sought indeed to emulate Pericles' example, his remarks on the latter's contentment with a foliage crown would not perhaps have been consistent with his having frequently sought or accepted the award of gold crowns. We may perhaps infer that most, if not all, the crowns commemorated in 3207 had been of foliage. Few, if any, of the decrees had probably been inscribed before. The process for Lykourgos parallels in some respects that which can be observed on another inscription we have already mentioned: Demosthenes of Lamptrai's decree of 325/4 for the grain trader, Herakleides of Salamis $\left(I G \|^{3} 1,367,1-28\right)$, according to which the prytany secretary was to inscribe not only his own decree, awarding Herakleides the proxeny, but also

\footnotetext{
The case for a connection between this Telemachos and the Telemachos who founded the Athenian cult of Asklepios in 420 BC is tenuous. See Lambert, Historia 59 (2010), 156-57.

${ }^{36}$ See $I G \|^{3} 1,432$, for Sopatros of Akragas, and the references to the grain supply in Against Leokrates.

${ }^{37}$ See the translation on $\mathrm{AIO}$ of $I G \|^{3} 1,447$, with notes.

${ }^{38}$ As for example the Council decrees, decrees II-V of $\underline{I G \|^{3} 1,306}$. Note also the Council

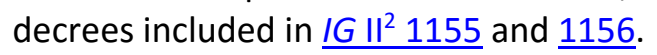

${ }^{39}$ Cf. J. Blok and S. D. Lambert, ZPE 169 (2009), 95-121, at 105-14.

${ }^{40}$ The sort of dynamic in play here is illustrated by Aeschin. 3.125, where Aeschines portrays Demosthenes as prevailing on a councillor to put a probouleuma of his through the Council,

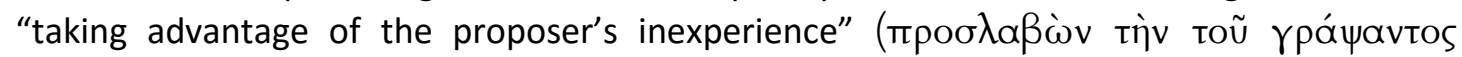
ámeipíav). On the relative obscurity of proposers in the Council see M. H. Hansen, The Athenian Democracy in the Age of Demosthenes (1991), 145-46.
} 
the "other praises that there have been for him" (toùs ă $\lambda \lambda$ ous Émaívous toùs

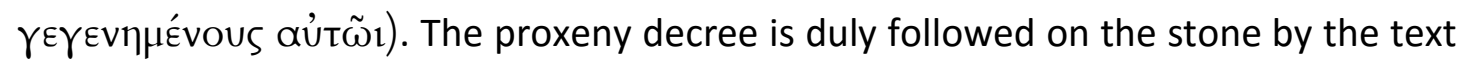
of four earlier decrees (fully transcribed on this occasion), which had patently not been inscribed previously, and the texts of which had, it seems, been obtained from the papyrus archive of decrees in the Metroon. Insofar as the decrees honouring Lykourgos were of the Council or Assembly, the information about them on which $\underline{3207}$ was based perhaps also derived from the Metroon archive. The decrees honouring Herakleides had not previously been inscribed because, at this period, it was simply not normal to inscribe awards of crowns to individual foreigners without substantive accompanying honours such as the proxeny or citizenship. In the case of Athenian citizens, decrees awarding crowns only were sometimes inscribed from the 340 s onwards, but for the inscribing to be at public expense, the crowns had at this period normally to be of gold, rather than foliage. ${ }^{41}$ Crowns awarded by the Council on its own authority (crowns 5, 6 and 7) were also usually of foliage and the decrees awarding them were not usually inscribed. ${ }^{42}$

\footnotetext{
${ }^{41}$ Cf. ZPE 150 (2004), $88=$ IALD 8.

${ }^{42} \underline{I G ~} \|^{2} 1155$ decree 1 (?) and $\underline{1156}$ decree 2 are exceptions which prove the rule in that they both record awards of foliage crowns by the Council on its own authority, but were inscribed not at the Council's initiative, but that of the honorands or their tribe (Kekropis in both cases). See the translations on AIO.
} 